\title{
ÖZ ŞEFKAT KAVRAMI VE ÖRGÜTSEL YANSIMALARI
}

Rabia ÖZPEYNIRCI 1

Canan KIRMIZI 2

$\ddot{O Z Z}$

\section{Anahtar Kelimeler:}

Öz Şefkat,

Örgütsel Davranış

JEL Kodları:

M10,

M19
Received Date (Başvuru Tarihi): 3/07/2020

Accepted Date (Kabul Tarihi):

$27 / 08 / 2020$

Published Date (Yayın Tarihi):

$25 / 09 / 2020$
Keywords:

Self Compassion

JEL Codes:

M10
Öz şefkat Doğu felsefesinde nicedir ele alınan bir kavram olmasına rağmen Batı psikolojisinde etkileri yeni değerlendirilmeye başlanmış ve son yıllar içerisinde geniş bir çerçevede araştırmalarda kendine yer bularak önemli pozitif psikoloji kavramlarından biri haline gelmiştir. Öz şefkat ile yapılan çalışmalarda kavramın umut, mutluluk ve yaşam doyumu gibi pek çok olumlu değişken ile ilişkili olduğu gözlemlenmiştir. Örgütsel davranış literatüründe ise öz şefkate ilişkin çalışmaların sinırlı kaldığı görülmekte olup kavramın săgladığı olumlu etkilerin alana taşınması ile örgütlerin daha mutlu ve verimli çalı̧̧anlara sahip olabileceği düşünülmektedir. Bu bağlamda çalışmanın amacl; öz şefkat kavramı, boyutlar ve ilişkili olduğu değiş̧enlerle ilgili kavramsal çerçeveyi ortaya koyarak, örgütsel davranış literatüründe kullanılabilirliğine dikkat çekmektir. Bu doğrultuda yurt dışı ve yurt içi literatür taraması yapılarak öz şefkatin genel bir kavram haritası çıkartılı örgütsel alan içerisindeki yansımalarının kavramsal bir değerlendirilmesi yapılmaya çalışılmıştır. Bu kapsamda ele alınan araştırmalar, öz şefkatin örgütsel anlamda gerek yönetici gerekse çalışanlara katkı sağlama potansiyelini ortaya koymuştur.

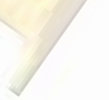

\footnotetext{
${ }^{1}$ Doç. Dr., Karamanoğlu Mehmetbey Üniversitesi, rabiaozpeynirci@kmu.edu.tr,

${ }^{2}$ Arş. Gör., Karamanoğlu Mehmetbey Üniversitesi, canankirmizi@kmu.edu.tr,
}

https://orcid.org/0000-0002-3547-7664 https://orcid.org/0000-0002-5813-1420 


\section{EXTENDED ABSTRACT}

\section{THE CONCEPT OF SELF COMPASSION AND IT'S ORGANIZATIONAL REFLECTIONS}

\section{LITERATURE}

Although the concept of self-compassion has been around in Eastern philosophy for a long time, its effects have just started to be evaluated in Western psychology. It has become one of the essential positive psychology concepts by taking part in a wide range of academic researches in recent years. The concept, rooted in the Buddhist tradition, was brought to Western psychology by Neff (2003a).

Self-compassion simply defined as compassion directed inward. It involves open to one's suffering, not disconnecting or avoiding it, generating the desire to heal oneself with kindness, and to alleviate one's suffering. It includes three primary dimensions, namely self-kindness versus selfjudgment, common humanity versus isolation, and mindfulness versus over-identification (Neff, 2003b, s. 87)

Many researchers have studied on self-compassion. Meta-analyses and systematic reviews have linked that self-compassion was more strongly related to many positive outcomes, such as optimism, happiness, overall well-being (Zessin et al. 2015). Additionally, it has been associated with less stress, anxiety and depression (Luo et al. 2019). However, it seems that the effects of self-compassion in the organizational behaviour field are not sufficiently explored. It is noteworthy that most of these studies are carried out within the health and education field. Limited studies have done in the organizational field also show that compassion affects many critical organizational outcomes such as performance and creativity. It is thought that organizations can have happier and more productive employees by bringing the positive effects of the concept to the field. It has the potential for contributing to both managers and employees. Therefore, self-compassion researches from an organizational perspective should be enhanced. In this respect, this study is considered to be a useful review in light of current researches. It is hoped that the study will provide a guide for researchers.

\section{DESIGN AND METHOD}

This study has the characteristics of a formal review and focused on the concepts or theories that explain or describe the self-compassion. It aims to provide a general perspective on the concept of self-compassion; its dimensions, related variables, and to draw attention to the usability of the concept in the organizational behaviour field. Accordingly, the study consists of three main parts. First, the concept of self-compassion was evaluated within the scope of different approaches, and the dimensions of the concept were explained. In the second part, the theoretical and empirical development of selfcompassion is detailed. National and international relevant literature has been scanned, and recent studies associated with self-compassion have been reviewed. In the third part, the reflections of selfcompassion on the organization were examined in line with the researches.

\section{FINDINGS AND DISCUSSION}

In this study firstly, the development of self-compassion was discussed in light of the relevant literature. It is observed that there has been a gradual increase in the number of research of selfcompassion in recent years, and these researches have explored different aspects of self-compassion. Similarly, in Turkey, this concept has gained attention. However, it is seen that the academic accumulation in the self-compassion literature is at the beginning stage. In this respect, it is seen that more theoretical and empirical studies are needed.

Recent studies have claimed that the current conceptualization of self-compassion and the way this trait is currently assessed with the Neff's scale are inappropriate and not in keeping with the true nature of this positive psychology construct. In this context, the five-dimensional structure (Strauss et al. (2016)) and scale (Gu et al. (2020)) should be evaluated with future research. 
In the last part of the study, the effects of self-compassion on the organization were reviewed. It has been observed that employees with a high level of self-compassion show more loyalty to their organizations (Yalap \& Baygın, 2020), exhibit more prosocial behaviours, and can quickly eliminate negativities such as stress and burnout (Dev et al., 2018). It is also mentioned that self-compassion is associated with creativity (Zabelina \& Robinson, 2010) and emotional intelligence (Fabio \& Saklofske, 2020) and has an enhancing effect on performance (Neff \& Knox, 2017). Further studies should be conducted on different samples in order to make a general inference.

\section{CONCLUSION, RECOMMENDATION AND LIMITATIONS}

As a result, self-compassion is seen as one of the essential individual strengths in psychology literature and is related to many positive concepts. Hence, it can be predicted as an essential determinant of desired behaviours in the organizational field. Therefore, the concept should be examined for both employees, and managers aspects in different areas and its relationship with variables within the scope of organizational behaviour should be revealed. In future research, it is suggested to reveal the relationship between self-compassion and organizational alienation, organizational loneliness, organizational identification. At the same time, it is thought that the studies to be carried out about personality and generations will contribute to understanding individual differences in the level of selfcompassion.

In this context, this study is expected to be a guide in order to increase the number of studies in the organizational context, which is relatively less studied in the expanding self-compassion literature. On the other hand, this study also has some limitations that need to be addressed. The most important limitation of the study is that there are no empirical results; conceptual evaluations are included. Also, they are limited to the accessible resources available to databases that we had access to. 


\section{GİRIŞ}

Batı psikolojisine yeni kazandırılmış kavramlardan biri olan öz şefkatin son yıllarda artan bir ivme ile araştırmalara konu olduğu görülmektedir. Psikoloji alanında önemli değişkenlerden biri haline gelen kavram pek çok farklı bilim dalı içerisinde de kendine yer edinmiştir. İnsana olan katkısı gün yüzüne çıktıkça, öz şefkatin kişilerde nasıl oluştuğu ve öz şefkat düzeyinin hangi değişkenlerle ilişki içerisinde olduğu da merak edilmektedir. Bu bağlamda öz şefkatle ilgili yapılan çalışmaların son yıllarda çeşitlendiği gözlemlenmektedir.

Pozitif psikoloji kapsamında yer alan öz şefkat, bireylerin başkalarına gösterdiği şefkati kötü durumlarda kendisine de gösterebilmesidir. Kavram olumsuz durumlarla başa çıkmada önemli içsel kaynaklardan biri olarak değerlendirilmektedir. Öz şefkat bireyin kendi acı, başarısızlık ve yetersizliklerini yargılamadan anlamaya çalışması olarak da ifade edilir (Neff, 2003b, s. 87). Farkındalığı da içeren bu tutum bireye yaşadığı olaylara yönelik geniş bir perspektif kazandırır. Öz şefkat düzeyi geliştirilebilir ve yaşantılar karşısında bireyin kendisine neler söylediği, kendi fikir ve eylemlerini nasıl değerlendirdiği öz şefkat gelişiminde etkilidir (Öveç, 2007, s. 37).

Öz şefkat pek çok değişken ile incelenmiş ve ruh sağlığına olan etkileri araştırmalar içerisinde konu edilmiştir. Olumlu duygular ile ifade edilen kavram, literatüre paralel olarak yaşam doyumu, mutluluk ve iyimserlik gibi pek çok pozitif kavramla ilişkili bulunmuştur (Neff 2003a; Hollis-Walker ve Colosimo, 2011). Yapılan çalışmalar (Breinesa, Toole ve Chen, 2014; Finlay-Jones, Kane ve Rees, 2017; Neff, 2003a; Neff, Hsieh ve Dejitterat, 2005) içerisinde öz şefkat; stres, depresyon, kayg1 ve başarısızlık korkusu gibi olumsuz durumlarda bireyi koruyan faktörlerden biri olarak değerlendirmiştir. Bu açıdan yaşama devam etme motivasyonunu korumak adına öz şefkat gelişimi önemlidir.

Öz şefkatin etkilerinin örgütsel davranış boyutuyla yeterince keşfedilmediği görülmektedir. Oysaki belirsizlikler ve stres altında çalışan kişiler için öz şefkat önemli bir güç olabilir. Giderek artan rekabet ortamı, hızlı değişen koşullar ve hissedilen başarı baskısı çalışanların yükümlülüklerini her geçen gün daha da arttırmaktadır. Bu 
noktada artan yükümlülükler çalışanlar üzerindeki stresi de artırmakta, pek çok çalışan yaşadıkları bu stresi yönetmekte zorlanmaktadır. Başa çıkılamayan bu tür olumsuzlukların ileri safhalarda psikolojik rahatsızlıklara neden olduğu karşılaşılan durumlar arasındadır. Bu açıdan çalışanların stresi yönetip, olumsuz durumlarda kendilerini rahatlatarak kontrollerini kaybetmemeleri önemlidir. Çalışanlarını önemseyen ve daha etkin bir performans isteyen tüm örgütler de bu durumlarda çalışanlarına yol gösterici çözümler üretmelidir. İşte bu noktada pek çok olumlu değişken ile ilişkili olduğu keşfedilip geliştirilebilir bir güç olarak literatürde kendine yer bulan öz şefkat kavramının etkilerini örgüte taşımak faydalı olabilir.

İşletmelerde yapılan sınırlı çalışmalar öz şefkatin pek çok önemli örgütsel çıktıyı etkilediğini de göstermektedir. Bu yapılan çalışmaların çoğunun sağlık ve eğitim sektörü kapsamında yürütüldüğü görülmektedir. Bu dayanakla öz şefkatin farklı sektörlerde çalışanlar üzerindeki etkisi incelenmeli ve öz şefkatin örgütsel yansımalarını içeren genel bir çerçeve çizilmelidir. Bu doğrultuda çalışmanın ana amacı, öz şefkat kavramının genel sınırlarını ortaya koyarak örgütsel davranış literatüründe kullanıbilirliğine dikkat çekmektir.

Çalışma üç ana bölümden oluşmaktadır. İlk olarak öz şefkat kavramı farklı yaklaşımlar kapsamında değerlendirilmiş ve kavramın boyutları açıklanmıştır. İkinci kısımda öz şefkatin teorik ve amprik anlamda dünden bugüne gelişimi detaylandırılarak kavram ile ilgili yapılan güncel çalışmalar aktarılmıştır. Böylelikle hızla gelişen öz şefkat literatürünü takip etmek isteyen araştırmacılara bir yol haritası çıkarılmıştır. Üçüncü kısımda ise öz şefkatin örgüte yansımalarının neler olabileceği yapılan araştırmalar doğrultusunda incelenmiştir.

\section{2. ÖZ ŞEFKAT KAVRAMI}

Kaynağını Budist felsefesinden alan öz şefkat kavram olarak Neff (2003a) tarafından literatüre kazandırılmıştır. Buda'nın öğretilerinden meydana gelen Budist felsefe benliğin olumsuz etkilere yol açan duygulardan arındırılması temeline dayanmakta ve bu yolda bireyin kendisine de şefkat göstermesi gerektiğini vurgulamaktadır. Bu açıdan öz şefkat Budizm içerisinde uzun yıllardır bilinen bir olgu olarak karşımıza çıkmaktadır (Omay, 2019, ss. 49-50). 
Öz şefkat kavramını anlamlandırabilmek için öncelikle şefkat olgusunun çerçevesini çizmek gereklidir. Latince "compati" kökünden gelip İngilizce'de "compassion" olarak ifade edilen şefkat "acı çeken biri için üzülmek ve onu anlamak" manası ile kullanılagelmiştir (The Oxford Dictionary, 2000, s. 133). Genel anlamda başkalarının kederlerini fark edebilmeyi ve bu kederlere karşı duyarlı davranarak onları hafifletmek ya da ortadan kaldırmak için harekete geçmeyi içeren sosyal bir süreç olarak açıklanır (Nas ve Sak, 2020, s. 66).

Şefkat Batı dünyasında önemli bir erdem olarak sayılmakla birlikte sadece başkalarının sıkıntılarına karşı hissedilen bir duygu olarak kabul edilmektedir. Budist kökenli psikolojide ise sadece başkalarının kederleri karşısında değil, bireyin kendi kederleri karşısında da göstermesi gereken bir his şeklinde ifade edilir. Budist felsefesi, bireyin başkalarına şefkatli, duyarlı ve sevecen olabilmesi için öncelikle kendisine karşı şefkatli olmasının gerekliliğini vurgulamaktadır (Bennet-Goleman, Brach ve Hanh aktaran Neff, 2004, s. 28). İşte Doğu-Batı arasındaki bu bakış açısı farklılığı öz şefkat olgusunun gelişmesine zemin hazırlamıştır. Kavramın dilimize çevirisinde "öz anlayış", "öz duyarlılık"ve "öz şefkat" terimlerinin kullanıldığı görülür. Bu çalışmada ise öz şefkat teriminin kullanılması tercih edilmiştir.

Öz şefkat genel anlamda bireylerin şefkatli tutum ve eylemlerini kendine yönlendirmesidir. Bireylerin ıstırap, acı, yetersizlik ve başarısızlık hislerine kapıldığı kötü zamanlarında kendilerine karşı nazik ve sevecen olması, negatif duygularının farkına vararak bunları kabul edebilmesi ve yaşanabilecek zorlukların insan yaşamının bir parçası olduğunu bilmesi şeklinde tanımlanmaktadır (Neff, 2003b, s. 87).

Kavram Batı perspektifinde şu ana kadar Sosyal Psikolojik Yaklaşım (Neff, 2003a; 2003b; 2008) ve Evrimsel Sinirbilimsel Yaklaşım (Gilbert, 2005; 2009) kapsamları içerisinde değerlendirilmiştir. Sosyal psikolojik yaklaşım daha çok öz şefkate sahip olabilmek için gerekli bireysel yetenekleri ve öz şefkatin psikolojik iyi oluş üzerine etkilerini anlamaya odaklanmıştır. Sağlıklı ilişkiler kurmak adına öz şefkatin diğer psikolojik yapılarla olan ilişkisini tanımlamaya çalışmıştır. Evrimsel sinirbilimsel yaklaşım ise sosyal psikolojik yaklaşımın aksine şefkat gelişimine odaklanmakta ve bu 
gelişimi, deneyimlerin şekillendirdiği bireysel beyin süreçleri üzerinden evrimsel bir model aracılığıyla açıklamaktadır.

\subsection{Sosyal Psikolojik Yaklaşım Açısından Öz-Şefkat}

Sosyal psikolojik yaklaşım kapsamında Neff (2003a), öz şefkatin başarısızlık ve acıların tecrübe edildiği zamanlarda ortaya çıkan üç temel bileşene sahip olduğunu belirtmektedir. Bunlar; öz yargılamaya karşı öz sevecenlik, izolasyona karşı ortak paydaşımların bilincinde olma, aşırı özdeşleşmeye karşı bilinçli farkındalıktır. Bu alt boyutlar kavramsal olarak birbirinden farklı olmasına rağmen etkileşim halindedir. Birbirlerinin oluşumuna veya gelişimine katkıda bulundukları söylenebilir. Her boyut kendi içerisinde olumlu ve olumsuz bir bileşen barındırmaktadır. Neff (2003a) işlevsel olması adına bu boyutları üç ana başlık altında toplamıştır; öz sevecenlik, ortak paydaşım ve bilinçli farkındalık.

Öz sevecenlik; bireylerin ön yargıdan uzak bir şekilde kendilerini anlamaya çalışmasıdır (Kirkpatrick, 2005, s. 5). Bireylerin kusurlarına yönelik yaptıkları eleştirilerin daha sempatik ve destekleyici olması gerektiği ile ilgilidir. Olası bir başarısızlık durumunda bireyin kendini acımasız biçimde eleştirmek yerine sevecenlik ve nezaketle durumu karşılaması öz sevecenlik kapsamında değerlendirilir. Hatalara tolerans ve anlayışla yaklaşmak ve mükemmelliğin ulaşılamaz olduğunu kabullenmek önemlidir (Neff ve Tirch, 2013, s. 81). Kendini yargılamanın tam tersi olan öz sevecenlik, bireyin hataları sebebiyle kendine olan öfkesini anlayışa ve şefkate dönüştürmesini sağlar. Böylelikle bireylerin kendilerini daha doğru değerlendirebileceği öngörülmektedir (Leary ve diğerleri, 2007, s. 887).

Kendini yargılamanın tam tersi olan öz sevecenlik, bireyin hataları sebebiyle kendine olan öfkesini anlayışa ve şefkate dönüştürmesini sağlar. Böylelikle bireylerin kendilerini daha doğru değerlendirebileceği öngörülmektedir (Leary ve diğerleri, 2007, s. 87). Yaptıkları hatalara odaklanmak yerine bireylerin kendi esenliklerine, mutluluklarına, acılardan özgürleşmeye ve aydınlanmaya odaklanmaları daha yerinde bir hareket olarak görülmektedir (Wallace aktaran Kirkpatrick, 2005, s. 5).

Paylaşımların bilincinde olma şeklinde de ifade edilen ortak paydaşım boyutu; bireylerin hayatın mutlu ya da üzüntülü dönemlerinin sadece kendilerine özgü 
olmadığına ve diğerlerinin de benzer süreçleri yaşadıklarına dair farkındalığa sahip olması olarak açıklanır (Akın, Akın ve Abacı, 2007, s. 2). Bu farkındalık bireyin kendisine ve yaşadıklarına daha geniş bir pencereden bakmasına olanak tanır. Böylelikle kötü bir durumla karşılaşıldığında verilen 'neden ben' tepkisi azalır, olumsuzlukların da insanoğlunun ortak deneyimlerinin bir parçası olduğunun bilincine varılır. Başkalarının da aynı tecrübeleri yaşadıklarını bilmek bireylerin hissettiği mahrumiyet ve eksiklik duygusunu azaltır (Germer ve Neff, 2013, s. 857). İzolasyonun tam tersi olan ortak paydaşım, insanların birbirlerine bağlı ve ilişkili olduklarını vurgulamaktadır (Kirkpatrick, 2005, s. 7).

Sosyal psikolojik yaklaşım kapsamında Neff ‘e göre öz şefkatin üçüncü bileşeni olan bilinçli farkındalık; herhangi bir yargılama yapmadan iç ve dış uyaranları devam eden akış içerisinde gözlemlemeyi ifade eder. Marlatt ve Kristeller (1999) kavramı, bireyin tüm dikkatini tüm benliği ile yaşadığı deneyime taşıması olarak açıklamaktadır (Akt. Baer, 2003, s. 125). Bilinçli farkındalık, açıklık ve kabulü içeren kendine odaklanmış dikkat hali olarak da tanımlanır. Bu farkındalık mevcut anın gerçekliğine açık olup tüm fikir, duygu ve algıları yargılamadan, baskılamadan ya da kaçınmadan kabullenmeyi kapsamaktadır. Böylelikle birey düşünceleri ve duyguları ile savaşmak yerine anlamaya çalışarak en doğru davranışa kolaylıkla ulaşacaktır (Bishop ve diğerleri, 2004, s. 237).

Bilinçli farkındalık öz şefkatin temel unsurlarındandır. Çünkü bireylerin kendilerine şefkat gösterebilmeleri için öncelikle yaşadıkları acıyı fark edebilmeleri lazımdır. Olumsuzluklar ne kadar belirgin olsa da bazı bireyler ne kadar acı içinde olduklarını ve bu acıların kendi içsel eleştirilerinden kaynaklandığını itiraf etmekte zorlanır. Ek olarak yaşadığı olumsuzlukları hemen çözmeye odaklanan bireyler duygusal olarak ne kadar zorlandıklarını umursamamaktadır. İşte bilinçli farkındalık bireylerdeki bu kaçınma eğilimini azaltır ve hoş olmayan durumlarda bile gerçeği görebilmemize olanak tanır (Neff ve Trich, 2013, s. 82).

Bilinçli farkındalık, deneyimlerin sadece olumsuz yanlarına takılı kalmak olarak ifade edilen aşırı özdeşimin zıttıdır. Öz şefkatin bu unsuru ile birey olumsuzlukların kalıcı olmadığının ayrımına varır ve yaşadığı kötü durumun 
dünyanın sonu olmadı̆̆ına inanır (Neff, 2016, s. 265). Böylelikle bireyler sahip oldukları uyumsuz duygu, davranış ve düşünce şablonlarını daha doğru ve bilinçli bir biçimde algılama imkanına sahip olur (Brown, 1999).

Neff (2016) bahsedilen bu üç boyutun birbirini etkileyen ve birbirlerinin gelişimine olanak tanıyan bir düzen içerisinde olduğunu açılamaktadır. Yaşadıklarının tam anlamıyla farkında olamayan bireylerin kendine karşı şefkat ve sevecenlikle yaklaşamaması olasıdır. Buna benzer şekilde olumsuzlukları yalnızca kendisinin yaşamadığını ve üzüntülerin de ortak deneyimlerden sayıldı ğını göz ardı eden bireylerin yaşanan durumları doğru değerlendirmesi ise zorlaşır. Bu bireylerin sert ve eleştirel iç seslerini susturmaları kolay olmayacaktır. Bu anlamda bu üç bileşen birbiriyle yakından bağlantılıdır. Her bir boyut diğer boyutun oluşumuna katkı sunmakta ve bu boyutlar öz şefkatin ana iskeletini oluşturmaktadır.

Neff sosyal psikolojik yaklaşım kapsamında öz şefkati birkaç farklı psikolojik kuramsal temel üzerinden yorumlamış ve kavramı ilişkisel, hümanistik (insancıl) ve duygu düzenleme kuramları açısından değerlendirmiştir.

Öz şefkat kavramı ile en çok benzeşen kuramın ilişkisel kuram olduğu Neff (2003b) tarafından ifade edilmiştir. Jordan (1989)'ın kadınların psikolojik gelişimleri hakkında yapmış olduğu çalışmalarda yer alan kişisel empati kavramının da öz şefkatin içeriği ile uyuştuğu görülmektedir. Kişisel empati; bireylerin kendi davranışlarını yargılamadan açıklıkla benimseme süreci şeklinde kavramlaşmıştır. Jordan (1989), bireylerin kendisine duyduğu bu empatiyi daha önce reddettiği ve yargıladığı yönlerini şefkatle kabul eden bir 'düzeltici ilişki tecrübesi' olarak ifade etmektedir (Aktaran Neff, 2003b, s. 90). Bu tanımın Neff tarafından ortaya atılan öz şefkatin alt boyutları ile de örtüştüğü söylenebilir.

İnsanc1l (hümanist) kuram insanı kendi eylemlerini denetleyebilen özgür bir varlık şeklinde değerlendirmektedir. Bu açıdan insancıl kuram öz şefkat ile belirgin ilişkiye sahip kuramlardan biri olarak kabul edilir. Kuramın önemli düşünürlerinden Maslow (1968) bireylerin gelişimi için başarısızlıklarını ve kendi sorunlarını kabul etmelerinin önemli olduğunu vurgulamıştır (Öveç, 2007, s. 30). Rogers (1961)'ın geliştirdiği koşulsuz kabul kavramı ile öz şefkatin örtüştüğü görülmektedir. Koşulsuz 
kabul; benliğimizde bulunan sevmediğimiz yönlerimizi dahi aşamalı olarak kabul etmeye ve içselleştirmeye yardımcı olur ve kendimizi anlamamıza imkân tanır. İnsanc1l kuram sağlıklı insanı benliği ile ilgili farkındalığı sahip ve bu farkındalıkla topluma uyum gösterebilen insan olarak tanımlamaktadır (Rogers, 1961). Bu bilgiler 1şı̆̆ında öz şefkatteki farkındalık süreci ile insancıl kuramdaki farkındalık sürecinin ilişkili ve benzer olduğu söylenebilir.

Aynı zamanda öz şefkatin son yıllardaki duygusal düzenleme çalışmalarıyla da ile ilgili olduğu görülmektedir. Bu çalışmalar, bireylerin duygularını kontrol edebilme ve yönetebilme becerisi kazanarak sosyal hayata adapte olmasını kolaylaştıran yaklaşımları içermektedir (Mete, Vakkas ve Aksoy, 2016, s. 15). Duygusal düzenleme kişilerin stresli olaylarda durumun anlam ve yapısına uygun bir şekilde duygularını dönüştürebilmesini sağlar. Bu temelde son yapılan çalışmalar öz şefkatin önemli başa çıkma ve duygusal düzenleme stratejilerinden biri olduğunu bizlere göstermektedir (Diedrich, Hofmann, Cuijpers ve Berking, 2014). Birey öz şefkat ile yaşadığ durumu daha net ve açık bir şekilde görebilir, negatif olan duygularını pozitife çevirerek kendisine ve çevresine uygun bir şekilde düzenleyebilir (Öveç, 2007, s. 37).

Ek olarak Kirkpatrick (2005), psikoanalitik kuram içerisinde yer alan Winnicott'tun (1953) ortaya attığı gizil boşluk kavramının öz şefkat ile yakından ilişkili olduğunu söylemektedir. Bebek dünyaya ilk geldiğinde kendisini annesi ile bir bütün şeklinde algılar ve her isteğinin yerine getirildiği bir fantezi dünyasında yaşar. Bu dönemde "ben" algısı öne çıkmaktadır. Zaman içerisinde her istediğinin yerine getirilemeyeceğini ve anneden ayrı bir birey olduğunu keşfettiğinde çocukta 'ben değil algısı' gelişir. Sözü edilen gizil boşluk olgusu bu iki dönem arasındaki boşluğu kapsar. Çocuk olgunlaştıkça bu gerçek ve fantezi dünyasındaki gizil boşluğu yönetebilme becerisine sahip olur ve böylelikle öz şefkat duygusu oluşur (Kirkpatrick, 2005, ss. 17-18).

Çocuğun büyümesiyle kendisine olan farkındalığın da geliştiği görülür. Bu duruma paralel olarak çocuğun anne ile kurduğu bağ yavaş yavaş sona erer, ben-ben değil süreci öz şefkat duygusunun başlangıcını teşkil eder. Bu ben ve diğgerlerini bağlayan/aradaki alan hem ortak paydaşımı hem de farkındalığı hatırlatır. Bu şekilde 
çocuk genel bakış açısından sıyrılarak kendine ait bir bakış açısı kazanır (Ogden, aktaran Kirkpatrick, 2005, s. 18).

Son olarak bilişsel-davranışsal kuram içerisindeki pek çok müdahale yönteminin öz şefkati beslemeye yönelik olduğu görülmektedir. Danışanları daha az öz eleştiri ve daha çok öz anlayışa teşvik eden bu kuram danışanların kendi ihtiyaç ve isteklerine yönelik duydukları olumsuz değerlendirmelerini öz kabule dönüştürmeye çalışır (Greenberg ve diğerleri, aktaran Kirkpatrick, 2005, s. 19). Öz şefkatin temel ögelerinden olan bilinçli farkındalık, bilişsel davranışsal kuram içerisinde de önemli sayılmaktadır. Akla gelen düşünceler çarpık ya da gerçekçi olarak değerlendirilmez ve değiştirilmeye çalışılmaz. Danışanlara düşüncelerin kalıcı olmadığı ve onları yargılamamaları öğretilir. Gestalt kuramın öncüsü Perls, tıpkı öz şefkatteki gibi duygulardan kaçınmanın ya da onlara aşırı anlamlar yüklemenin işlevsel bozukluklara sebep olacağını belirtmiştir (Tatlılığlu, 2010, s. 22). Ayrıca duygusal davranışsal terapi bireyin sınırlılıklarını kabul edip hoş görmesini önermektedir. Bu yaklaşım öz şefkat ile yakından ilişkilidir (Öveç, 2007, s. 31).

\subsection{Evrimsel Sinirbilimsel Yaklaşım Açısından Öz-Şefkat}

Gilbert tarafından ortaya atılan bu yaklaşım bağlanma, beyin gelişimi ve sinirbilim arasındaki ilişkilerden yola çıkarak öz şefkatin etki mekanizmasını açıklamaktadır. Gilbert’a göre insanlarda motivasyon ve ödül ile bağlantılı olan dürtü sisteminden bağımsız olarak sakinlik, sosyal bağlantısallık ve güvenlik duygularını ortaya çıkaran bir "yatıştırıcı sistem" (soothing system) bulunmaktadır. Bu yatıştırıcı sistemin gelişimi direkt olarak erken dönemde bebek ile birincil bakım veren arasındaki ilişkinin kalitesine bağlıdır. Bir bebek kaygılı tepkiler verdiğinde onu yatıştıran bir ebeveynin varlığı bebekte duygu düzenleme sistemini uyarır ve böylelikle nöral bağlantılar aracılığıyla kalıcı bir 'yatıştırıcı sistem' kurulmaktadır. Bu sistem bireylerin kendilerini sakinleştirme becerilerini ve kendilerine yönelik şefkatli tutumlarını artırır (Korkmaz; 2018). Bu açıdan erken dönemde bebeğe gösterilen bakımın niteliğinin öz şefkat gelişiminde etkili olduğu öne sürülerek düşük öz şefkatin kökeninin bağlanma kuramıyla ilişkili olduğu açıklanmaktadır (Gilbert ve Procter, 2006; Neff ve McGeehee, 2010). 
Gilbert (2009) ortaya koyduğu şefkat odaklı terapi programında şefkatli bir tutuma sahip olabilmek için gerekli özellik ve becerileri sıralamıştır. Bu özellik ve becerilere sahip olanların kendileri ile olan ilişkilerinde daha şefkatli bir tutumu benimseyeceklerini öne sürerek bir zihin eğitim programı hazırlamıştır. Şefkatin sıralanan bu özellikleri arasında duyarlılık, iyi olmayı önemseme, sempati, yargılayıcı olmama, empati ve sıkıntıya katlanma yer alır. Becerilerde ise şefkatli dikkat, şefkatle mantık yürütme, şefkatle davranma, şefkatle hayal kurma, şefkatli hissetme ve şefkatli duyum vardır. Birey bu becerileri geliştirebildiği takdirde öz şefkatli bir duygu ve biliş sistemine kavuşmaktadır.

Şefkatli dikkat bireylerin dikkatlerini kendilerine destek ve fayda sağlayacak şekilde yönlendirmesidir. Olumsuz bir deneyim ile karşılaşıldı̆̆ında önceden yaşanan diğer olumsuzlukları hatırlamak yerine yönünü olumlu anılara çevirebilmeyi içerir. Böylelikle birey daha dengeli bir bakış açısıyla olayı çözümleyebilir. Şefkatle mantık yürütme dünya, diğerleri ve kendimiz hakkında nasıl düşündüğümüzü kapsamakta ve fayda sağlayacak alternatif düşünceler geliştirebilmeyi içermektedir. Şefkatli davranma ise sıkıntıları hafifletmek, büyüme ve gelişmeye odaklanmak şeklinde ifade edilir. Acı veren durumlarla yüzleşememek ya da zor görevlerden kaçınmak gibi davranışların aksine bireyin cesaretle yol alması bu beceri ile geliştirilmek istenendir. Şefkatli hayal kurma, bireylerin şefkat içeren görüntüleri imgeleme egzersizlerinden faydalanarak düşünme yapılarını şefkat yönünde geliştirebilmesine yönelik bir beceridir. Şefkatli hissetme diğer canlılara karşı şefkat duyabilme ve onlardan şefkat hissedebilme ile ilgilidir. Şefkatli duyum bireyin kendine ya da başkalarına karşı şefkat gösterdiğinde ya da başkalarından şefkat gördüğünde bedeninde oluşan duygulara odaklanmasıdır (Gilbert, 2009, s. 203-205).

\section{3. ÖZ ŞEFKAT KAVRAMININ ALANYAZINDA GELİŞIMİ}

Öz şefkat ile ilgili ilk çalışma Neff (2003a) tarafından üniversite öğrencileri üzerinde yürütülmüş olup, bu çalışma kapsamında öz şefkatin üç ana bileşeninin her birinin kendi içerisinde olumlu ve olumsuz iki alt kategoriye ayrıldığı (öz sevecenliğe karşı öz yargılama, paylaşımların bilincinde olmaya karşı izolasyon ve bilinçli farkındalığa karşı aşırı-özdeşleşme) 26 maddelik bir ölçek geliştirilmiştir. Geliştirilen 
bu ölçek en az 17 ülke diline çevrilerek pek çok akademik çalışmada kullanılagelmiştir (Muris ve Otgaar, 2020). Daha sonrasında gelişitirilen şefkat korkusu ölçeği (Gilbert, McEwan, Matos ve Rivis, 2011) ve öz şefkat ve öz eleştiri ölçekleri (SCCS) (Falconer, King ve Brewin, 2015) gibi alternatif ölçeklerin alanyazında sıklıkla kullanılmadığ1 gözlemlenmiştir. Raes, Pommier, Neff ve Van Gucht (2011) tarafından Neff' in öz şefkat ölçeğinin kısaltılmış versiyonu da nicel araştırmalar için tercih edilen ölçeklerden biri haline gelmiştir.

Sıklıkla tercih edilmesine rağmen Neff tarafından öz şefkat için öne sürülen kavramsal yapı çerçevesi ve bu çerçeve kapsamında geliştirilen ölçek son yıllarda farklı noktalar üzerinden eleştirilmektedir. Ölçek için yapılan ana eleştiri noktası, öz yargılama, aşırı özdeşleşme ve izolasyon şeklindeki olumsuz nitelikteki alt boyutların olumlu alt boyutlar ile ölçek içerisindeki mevcudiyetidir. Bu türde bir kavramlaştırmanın pozitif psikoloji yapısının gerçek doğasına uymadığına ve öz şefkate ilişkin doğru bir ölçüm yapamayacağına ilişkin çalışmalar görülmektedir (Khoury, 2019; Muris ve Otgaar, 2020).

Strauss ve diğerleri (2016) (öz) şefkatin çeşitli şekillerde kavramlaştırılmasına ilişkin literatürü kapsamlı bir şekilde taradıktan sonra, yapının temelde beş unsurdan oluştuğu sonucunu öne sürmüşlerdir: 1) acıyı tanımak, (2) insanın acı çekmesinin evrenselliğini anlamak, (3) acı çeken kişiye karşı empati geliştirmek, (4) rahatsız edici duyguları tolere etmek ve (5) harekete geçmek ya da acıyı hafifletmek için harekete geçme motivasyonuna sahip olmak. Oluşturulan bu tanımlamaya göre şefkat sadece bir duygu olmaktan öte; acıya karşı duyarlı olmayı, acıyı kabullenebilmeyi, acıyı tolere edebilmeyi, evrenselliğini anlamayı ve harekete geçebilmeyi içeren karmaşık bir yapıya sahiptir. Araştırmacılar daha önce yapılan (öz) şefkat tanımlamalarının hiçbirinde bu beş unsurun bir arada verilmediğini ileri sürerek kapsamlı ve yeni bir ölçek ihtiyacına bu araştırmanın temel sağlayabileceğini iddia etmişlerdir. Nitekim Gu ve diğerleri (2020) bu teorik yapıyı kullanarak ikisi de 20 maddeden oluşan SussexOxford Başkalarına Şefkat Ölçeği (SOCS-O) ve Sussex-Oxford Öz şefkat (SOCS-S) Ölçeklerini geliştirmişlerdir. 
Muris ve Otgaar (2020) yaptıkları araştırmada öz şefkat ile ilgili son on yıldır yürütülen çalışmaların çoğunluğunda öz şefkatin koruyucu işlevine odaklanıldığını belirtmişlerdir. 2019 yılında yapılan öz şefkat ile ilgili çalışmaların önemli bir kısmı nicel niteliktedir ve bu çalışmalarda öz şefkat pek çok farklı değişken ile birlikte incelenmiştir (Muris ve Otgaar, 2020). Öz şefkatin yaşanılan olumsuzlukların etkilerini ve öz eleştiriyi kontrol ederek, anksiyete ve depresyonu azalttığı pek çok çalışmada tespit edilmiştir (Neff ve Germer, 2017). Yapılan son araştırmalar öz şefkatin öznel iyi oluş ile pozitif (Neely ve diğerleri, 2009; Neff, 2011; Zessin, Dickhauser ve Garbade, 2015), psikopatolaji ile negatif ilişkili (Macbeth ve Gumley, 2012) olduğunu gösteren önemli ve tutarlı deneysel sonuçlar içermektedir. Ayrıca öz şefkatin spor ve tıp alanlarında, iş ile ilgili stres (tükenmişlik, motivasyon ve erteleme) durumlarında, pozitif bir özellik olarak giderek artan bir şekilde daha fazla araştırıldı̆̆ gözlemlenmektedir (Muris ve Otgaar, 2020). Bu açıdan öz şefkat literatürünün genişleyerek kavram ile ilgili çalışmaların gerek örneklem grupları gerekse ilişkili olduğu değişkenler açısından çeşitlendiği söylenebilir. Bu bağlamda Tablo 1'de son yıllarda öz şefkat ile ilgili yurt dışında farklı örneklem grupları üzerinde farklı değişkenler ile gerçekleştirilen araştırmalar görülmektedir. 
Tablo 1. Öz Şefkat ile İlgili Yurt Dışında Yapılan Araştırmalar

\begin{tabular}{|c|c|c|}
\hline Yazar(lar)/Tarih & Örneklem Grubu & Sonuç \\
\hline $\begin{array}{l}\text { Yang, Zang ve Kou } \\
\text { (2016) }\end{array}$ & Yetişkinler & $\begin{array}{l}\text { Araştırma umut değişkeninin, öz şefkat ile yaşam } \\
\text { memnuniyeti ilişkisi üzerinde aracı etkiye sahip olduğu } \\
\text { sonucunu ortaya koymuştur. }\end{array}$ \\
\hline $\begin{array}{l}\text { Jacobson, Wilson, Kurz } \\
\text { ve Kellum (2018) }\end{array}$ & $\begin{array}{l}\text { Romantik İlişkisi } \\
\text { Olanlar }\end{array}$ & $\begin{array}{l}\text { Araştırma sonuçları çiftlerin öz şefkat düzeyleri ile } \\
\text { sahip oldukları romantik ilişkinin kalitesi arasında } \\
\text { anlamlı bir korelasyon olduğu sonucunu } \\
\text { göstermektedir. }\end{array}$ \\
\hline Kim ve Ko (2018) & Yaşlılar & $\begin{array}{l}\text { Araştırma, öz şefkatin sahip olduğu olumlu bileşenlerin } \\
\text { yaşlılarda depresyon ve uyku bozukluklarını } \\
\text { azaltmada ve yaşam memnuniyetini artırmada etkili } \\
\text { olduğu sonucuna varmıştır. }\end{array}$ \\
\hline Luo ve diğerleri (2019) & $\begin{array}{l}\text { Hemşirelik Bölümü } \\
\text { Öğrencileri }\end{array}$ & $\begin{array}{l}\text { Araştırma öz şefkatin algilanan stres üzerinden } \\
\text { anksiyete ve depresyonu etkilediği sonucunu ortaya } \\
\text { koymuştur. }\end{array}$ \\
\hline Khoury (2019) & Teorik Çalışma & $\begin{array}{l}\text { Başkalarına ve kendine yönelik şefkatin teorik temelleri } \\
\text { üzerine bir derleme yapan çalışma, şefkatin bilişsel } \\
\text { duyuşsal, davranışsal ve kişiler arası süreçler üzerinden } \\
\text { incelenmesi gerektiğini ifade etmiştir. }\end{array}$ \\
\hline $\begin{array}{l}\text { Wilson, Weiss ve Shook } \\
\qquad(2020)\end{array}$ & $\begin{array}{l}\text { Psikoloji Bölümü } \\
\text { Öğrencileri }\end{array}$ & $\begin{array}{l}\text { Araştırmada algılanan sosyal desteğin, öz şefkati, } \\
\text { bilinçli farkındalığı ve memnuniyeti teşvik ederek iyi } \\
\text { oluşu geliştirdiği sonucuna varılmıştır. }\end{array}$ \\
\hline $\begin{array}{l}\text { Allen, Roberts, Zimmer- } \\
\text { Gemmek ve Farrell } \\
\text { (2020) }\end{array}$ & Ergenler & $\begin{array}{l}\text { Araştırmada öz şefkat düzeyi yüksek olan ergenlerin, } \\
\text { beden algısı bozukluklarına yönelik algı düzeylerinin } \\
\text { daha düşük olduğu sonucuna ulaşılmıştır. }\end{array}$ \\
\hline Muris ve Otgaar & Teorik Çalışma & $\begin{array}{l}\text { Araştırma öz şefkate yönelik Neff'in geliştiştidiğgi } \\
\text { tanımlamanın sınırlı olduğunu ve ölçeğin olumsuz } \\
\text { boyutları da içermesi sebebiyle uygun değerlendirme } \\
\text { yapamadığını öne sürmektedir. }\end{array}$ \\
\hline $\begin{array}{l}\text { Stoeber, Lalova ve } \\
\text { Lumley (2020) }\end{array}$ & $\begin{array}{l}\text { Üniversite } \\
\text { Öğrencileri }\end{array}$ & $\begin{array}{l}\text { Araştırmada elde edilen bulgular; mükemmeliyetçiliğin } \\
\text { bazı boyutları ile öznel mutluluk arasında var olan } \\
\text { negatif ilişkiyi, düşük öz şefkat düzeyinin açıkladığını } \\
\text { ileri sürmektedir. }\end{array}$ \\
\hline
\end{tabular}

Tablo 1'de görüldüğü üzere yapılan çalışmalar öz şefkatin pek çok farklı örneklem grubu (ergenler, yetişkinler ve yaşlilar) ve değişken (umut, iyi oluş, ilişki kalitesi...) üzerinde etkili olduğunu bizlere göstermektedir. Yapılan nicel çalışmalar 
gerek ruhsal (anksiyete, depresyon, mükemmelliyetçilik) gerekse fiziksel (uyku ve yeme bozuklukları) olumsuzlukların azaltılmasında öz şefkatin öneminden bahsetmektedir. Son yıllarda kuramsal çalışmalarda öz şefkat kavramına yönelik bakış açılarının çeşitlenmesi, özellikle öz şefkatin boyutları bazında daha fazla kuramsal çalışmaya ihtiyaç olduğu gerçeğini ortaya çıkarmaktadır.

Ülkemizde öz şefkat ile ilgili yapılan çalışmalar incelendiğinde ise Öveç (2007) tarafından yürütülen çalışmanın Türkçe alanyazındaki ilk çalışma olduğu söylenebilir. Üniversite öğrencileri üzerinde yapılan bu çalışma sonucunda öz şefkatin depresyon, stres ve anksiyete ile negatif yönlü bir ilişkiye sahip olduğu ortaya konulmuştur. Öz şefkat ölçeğini Türkçe'ye çeviren Deniz, Kesici ve Sümer (2008) yapmış oldukları çalışmada öz şefkat ile yaşam doyumu arasında anlamlı pozitif bir ilişki saptamışlardır. İlerleyen yıllarda diğer ülkelerde olduğu gibi ülkemizde de öz şefkat literatürünün genişleyerek kavram ile ilgili çalışmaların gerek örneklem grupları gerekse ilişkili oduğu değişkenler açısından çeşitlendiği söylenebilir. Buna dikkat çekmek adına aşağıda Tablo 2'de son yıllarda öz şefkat ile ilgili yurt içinde farklı örneklem grupları üzerinde farklı değişkenler ile yapılan araştırmalara yer verilmiştir. 
Tablo 2. Öz Şefkat ile İlgili Yurt İçinde Yapılan Araştırmalar

\begin{tabular}{|c|c|c|}
\hline Yazar(lar)/Tarih & Örneklem Grubu & Sonuç \\
\hline Işık (2018) & Yetişkin Kadınlar & $\begin{array}{l}\text { Gerçekleştirilen yüksek lisans tez çalışmasında, öz } \\
\text { şefkat düzeyindeki artışın, kadınlarda olumsuz yeme } \\
\text { tutumlarını azalttığı ve beden memnuniyetini arttırdığı } \\
\text { sonucuna ulaşılmıştır. }\end{array}$ \\
\hline $\begin{array}{l}\text { Alibekiroğlu, Akbaş, } \\
\text { Ateş ve Kırkdök (2018) }\end{array}$ & $\begin{array}{l}\text { Üniversite } \\
\text { Öğrencileri }\end{array}$ & $\begin{array}{l}\text { Araştırmada psikolojik sağlamlık ile yaşam doyumu } \\
\text { arasında öz şefkatin kısmi aracılık etkisi olduğu } \\
\text { sonucuna varılmıştır. }\end{array}$ \\
\hline Korkmaz (2018) & Teorik Çalışma & $\begin{array}{l}\text { Öz şefkatin psikolojik belirtiler üzerindeki etkilerini ele } \\
\text { alan derleme çalışması psikoterapi süreçleri } \\
\text { bağlamında öz şefkati tartışmaktadır. }\end{array}$ \\
\hline Dilmaç ve Baş (2019) & Ergenler & $\begin{array}{l}\text { Araştırma bulgularına göre öz şefkat ergenlerin } \\
\text { değerleri ve mizah tarzları ile pozitif yönlü bir ilişkiye } \\
\text { sahiptir. }\end{array}$ \\
\hline $\begin{array}{l}\text { Aktaran ve Üstündă̆ } \\
\text { Budak (2019) }\end{array}$ & Teorik Çalışma & $\begin{array}{l}\text { Bağlanma kuramı, öz şefkat ve beden imajı arasındaki } \\
\text { olası bağlantıları inceleyen derleme çalışmasında öz } \\
\text { şefkatin gelişimindeki bireysel farklılıkların daha fazla } \\
\text { incelenmesi gerektiği ifade edilmiştir. }\end{array}$ \\
\hline Yaşa (2019) & Sağlık Çalışanları & $\begin{array}{l}\text { Gerçekleştirilen tez çalışmasında, öz şefkat düzeyi } \\
\text { düşük olan sağlık çalışanlarının sahip oldukları } \\
\text { anksiyete düzeylerinin diğer çalışanlara oranla daha } \\
\text { yüksek olduğu sonucuna ulaşılmıştır. Ayrıca öz şefkat } \\
\text { ile bilişsel duygu düzenleme strateji boyutlarından } \\
\text { bazıları arasında anlamlı ilişkilerin varlığı tespit } \\
\text { edilmiştir. }\end{array}$ \\
\hline Altıparmak (2019) & Öğretmenler & $\begin{array}{l}\text { Araştırma, öğretmenlerin yaşamlarındaki amaç ve } \\
\text { anlam düzeylerinin artmasının psikolojik iyi oluş } \\
\text { düzeylerini arttırdığını ve öz şefkatin bu ilişkide kısmi } \\
\text { aracılık etkisi olduğu sonucunu ortaya koymuştur. }\end{array}$ \\
\hline $\begin{array}{l}\text { Ekşi, İkiz ve Başman } \\
(2020)\end{array}$ & $\begin{array}{l}\text { Üniversite } \\
\text { Öğrencileri }\end{array}$ & $\begin{array}{l}\text { Araştırmada öz şefkat, duyguları ifade etme ile } \\
\text { mutluluk korkusu arasında var olan ilişkide aracı bir } \\
\text { değişken olarak bulunmuş ve öz şefkat düzeyleri artan } \\
\text { öğrencilerin duyguların daha kolay ifade edebildiği } \\
\text { saptanmıştır. }\end{array}$ \\
\hline
\end{tabular}

Tablo 2'de görüldüğü gibi ülkemizde de öz şefkat pek çok farklı örneklem grubu (ergenler, kadınlar, öğretmenler...) ve değişken (psikolojik sağlamlık, mizah tarzları, beden imajı...) ile incelenmiştir. Türkiye'de gerek lisansüstü tez çalışmalarında gerekse makale çalışmalarında kendine yer bulan kavramın daha çok psikoloji ve eğitim bilimleri içerisinde üniversite öğrencileri üzerinde yürütüldüğü 
görülmektedir. Kuramsal açıdan kapsamlı çalışmalara az rastlanması ise önemli bir eksiklik olarak dikkat çekmektedir.

\section{4. ÖZ ŞEFKATİN ÖRGÜTSEL DAVRANIŞ LİTERATÜRÜNDEKİ YERİ}

Şefkat din, tıp ve sosyoloji alanlarında uzun yıllardır araştırılan bir kavram olmasına rağmen örgütsel davranış kapsamında kısa bir geçmişe sahiptir (Frost ve diğerleri, 2006). Şefkatin çalışma hayatı üzerinde oluşturduğu pozitif etki son yıllar içerisinde fak edilmiş ve şefkat birçok boyutu ile örgüt temelli çalışmalara dahil edilmiştir (Dutton ve diğerleri, 2002; Frost, Dutton, Worline ve Wilson, 2000). Bu çalışmalar içerisinde iş yerinde şefkatin bireysel ve örgütsel olmak üzere iki şekilde değerlendirildiği görülmektedir. Bireysel şefkat çalışma arkadaşlarının sıkıntılarını fark edip, stresli bir durum ile karşılaştıklarında onları rahatlatmayı içermektedir. Örgütsel şefkat ise üyelerden birinin yaşadığı bir acıyı toplu şekilde fark etmek, hissetmek ve tepki vermeyi kapsamaktadır. Şefkatli örgüt, çalışanların birbirine güvendiği ve birbirlerine destek olup acılarını paylaşarak birlikte çözümler ürettiği örgüt olarak değerlendirilir. Yapılan çalışmalar (Dutton ve diğerleri, 2002; Lilius ve diğerleri, 2003) şefkatin, çalışanlar ve iş arasındaki bağı değiştirerek, pek çok olumlu iş tutumu ve davranış çıktısını oluşturduğunu göstermektedir (Kanov ve diğerleri, 2004).

İş yerinde gelişen şefkatin varlığı çalışanların yaşadıkları kederden sonra bile olumlu hissetmelerini ve devam edebilmelerini teşvik etmektedir (Lilius ve diğerleri, 2003). Örgütlerde var olan şefkat çalışanlara bilinir ve görünür olduğunu hissettirerek yalnızlık duygusunu azaltır (Frost, Dutton, Worline ve Wilson, 2000). Çalışanların yaşadığı acılara karşı hiçbir merhametin gösterilmediği iş yerlerinde çalışanlarda memnuniyetsizliğin oluşup stresin arttığ1 gözlemlenmiştir (Lilius ve diğerleri, 2003). Şefkatin olmadığı örgütlerde çalışanlar arasında karşılıklı ilişkilerde sinirli ve hırçın yaklaşımlar gözlemlenmekte ve bu da çalışanların motivasyonlarının olumsuz etkilenmesine, verimli çalışamamasına ve iş değiştirme konusunda daha aceleci davranmasina neden olmaktadir (Simpson, 2012: 109).

Şefkat duygusunun geliştiği örgütlerde çalışanlar, işlerine daha bağlılık geliştirmekte (Grant, Dutton ve Rosso, 2008; Lilius ve diğerleri, 2008) ve 
performanslarının arttığı gözlemlenmektedir (Aboul-Ela, 2017). Hemşireler üzerinde gerçekleştirilen çalışmada, iş yerinde gelişen şefkatin, çalışanların yaratıcılığını artırarak, iş ile ilgili olumlu düşüncelerini güçlendirip, performanslarını yükselttiği sonucuna ulaşılmıştır (Moon ve diğerleri, 2016). Aynı zamanda çalışmalar, şefkatin çalışanlar arasında karşılıklı güven ve iletişimin kurulmasına yardımcı olduğunu göstermektedir (Lilius ve diğerleri, 2008).

Örgütlerdeki şefkat, başarma baskısını ve anksiyeteyi azaltarak, çalışanları tükenmişliğe karşı dirençli hale getirir (Frost, Dutton, Worline ve Wilson, 2000). Aynı zamanda örgüt içerisinde gelişen bu şefkatli iklim, çalışanlarda minnet duygusunun artmasını (Lilius ve diğerleri, 2008) sağlayarak çalışanların kendilerini daha değerli hissetmelerini kolaylaştırır. Öz şefkat ise başkalarına gerek duymadan bireyin bu şefkati kendisine göstermesini içerir. Kendini yargılamaktan uzaklaşarak olumsuz duygularla başa çıkabilmeyi kişiye öğretir (Neff, 2003b, ss. 86-87). Çalışanların öz şefkat düzeylerinin yükselmesi, şefkatin sağladığı pek çok faydayı örgütsel alana taşıyabilmesi anlamına gelir. Bu çerçevede öz şefkatin örgütsel değişkenlerle ilişkisi incelenmeye başlanmış ve bulunan anlamlı ilişkiler sonucunda araştırmalar sıklaştırılmıştır.

Yapılan çalışmalar bir direnç faktörü olarak belirtilen öz şefkat ile çalışanların yaşadığ1 tükenmişlik sendromu arasında anlamlı bir ilişkiyi ortaya koymaktadır. (Alkema, Linton ve Davies, 2008; Raab, 2014). Tükenmişlik sendromu, olumsuz kişisel ve mesleki sonuçlara sebebiyet veren çalışanların yaşadığı duygusal tükenme durumudur. Çalışanların bu tükenmişlik durumunu kabul etmelerine ve etkilerini tanımalarına öz şefkat yardımcı olur ve böylece çalışanların tükenmişliğin olumsuz sonuçlarıyla başa çıkması kolaylaşır. Öz şefkate sahip olan çalışanlar, stresi daha etkili yöneterek bu olumsuz durumları en az hasarla atlatır. (Dev ve diğgerleri, 2018, s. 86). Öz şefkat, sağlık personellerinde sık karşılaşılan tükenmişliğin koruyucularından biri olarak açıklanmaktadır (Kemper ve diğerleri, 2019).

Öz şefkatin aynı zamanda iş yerinde prososyal davranışları teşvik ettiği söylenebilir. Öz şefkat düzeyi yüksek olan bireyler düşük olanlara oranla; daha fazla duygusal, bağlantılı ve kabullenici; daha az kontrolcü bireylerdir (Neff ve Beretvas, 
2012, ss. 3-4). Bu da onları diğerlerine karşı empati ve şefkat geliştirmeye iter (Longe ve diğerleri, 2010). Bu niteliklere sahip olan bireylerin iş yerlerinde örgütsel vatandaşlık kapsamında değerlendirilen prososyal davranışlar sergiledikleri ve toplum ve örgüt yararını düşündükleri gözlemlenmiştir (Lindsay ve Creswell, 2014).

Öz şefkat düzeyindeki değişimin örgüte olan bağlılı̆̆ı da etkilediği bulunan sonuçlar içerisindedir. Öz şefkat çalışanlardaki örgüte karşı olumlu duyguları geliştirir ve çalışanlar arasındaki iletişimi güçlendirir. Bu çerçevede öz şefkat düzeyi yüksek olan çalışanlar diğerlerini de etkileyerek örgüte duygusal ve normatif olarak bağlı olan iş gücü sayısını yükseltir (Simoes ve diğerleri, 2016). Adalet bakanlığ1 personeli üzerinde yürütülen Türkçe alanyazındaki çalışmada da benzer sonuçlar elde edilmiş, öz şefkatin örgütsel bağlılı̆̆ı anlamlı olarak pozitif yönde etkilediği sonucuna ulaşılmıştır (Yalap ve Baygın; 2020, s. 63). Aynı zamanda Abacı ve Arda (2013) tarafından beyaz yakalı çalışanlar üzerinde yapılan araştırmada öz şefkat ile iş tatmini arasında anlamlı pozitif yönde bir ilişki olduğu da ifade edilmiştir.

Neff ve Knox (2017) tarafından yürütülen başka bir çalışmada öz şefkatin performans üzerindeki artırıcı etkisine dikkat çekilmiş ve bireylerde oluşan olumsuz duygular, zihinsel engeller, önleyici düşünceler ve başarısızlık korkusunun üstesinden gelmede öz şefkatin fayda sağlayan bir güç olduğundan bahsedilmiştir. Artan öz şefkat düzeyinin performansı olumlu etkilediği (Barnard ve Curry, 2011), amaçlara ulaşma (Neff, Hsieh ve Dejitterat, 2005) ve başarı hedeflerini sağlama (Akın, 2008) ile pozitif ilişkiye sahip olduğu, başka çalışmalarda bulunan sonuçlar arasındadır. Ek olarak yaratıcı düşünmeyi engelleyen kendini kınama ve yargılama halini bireyin fark ederek azaltmasına öz şefkatin yardımcı olduğu da ifade edilmektedir (Zabelina ve Robinson, 2010).

Hemşireler üzerinde yürütülen çalışmalarda (Heffernan, Quinn Griffin, McNulty ve Fitzpatrick, 2010; Kousar ve diğerleri, 2017; Şenyuva, Kaya, Işık ve Bodur, 2013) öz şefkat ile duygusal zekâ arasında pozitif bir ilişkinin varlığı tespit edilmiştir. Özellikle acı ve stres içerisindeki hastalar ile yakınlık kurup onlara profesyonel bir yaklaşım sunmak zorunda olan sağlık çalışanları için duygusal zekâ önemli bir bileşendir. Duygusal zekâ ve öz şefkate sahip olan sağlık çalışanlarının hastaları ve 
onların yakınlarını daha doğru anladıkları ve onlara daha hassas davrandıkları gözlemlenmiştir. Fabio ve Saklofske (2020) tarafından yapılan araştırmada duygusal zekâ öz şefkat gelişimini artıran birincil faktör olarak ele alınmıştır. Bu noktada çalışmalarda ortaya konulan öz şefkat ve duygusal zekâ arasındaki pozitif ilişki sağlık işletmeleri tarafından önemsenmeli ve çalışanlarda bu unsurların gelişimi için yöntemler düşünülmelidir (Şenyuva ve diğerleri, 2013, s. 7).

Aynı zamanda bakım hizmeti sunan mesleklere sahip olan bireyler için öz şefkat önemlidir. Kendine şefkat gösterme kabiliyetinden yoksun bireylerin başkalarına şefkat göstermekte de zorlanacakları düşünülmektedir. Ayrıca oldukça stresli ve yorucu olan bu işlerin yürütülmesi, pek çok pozitif duyguyu insana kazandıran öz şefkatin yardımıyla mümkün görünmektedir (Heffernan ve diğerleri, 2010, ss. 367-368).

\section{SONUÇ VE TARTIŞMA}

Bu çalışma kapsamında ilk olarak öz şefkatin alanyazındaki gelişimi mevcut araştırmalar ışı ğında incelenmiştir. Yapılan araştırmalar öz şefkat kavramına olan ilginin her geçen gün artarak kavramın pek çok farklı disiplin içerisinde kendisine yer bulduğunu göstermektedir. Ancak öz şefkat literatüründe oluşan akademik birikimin başlangıç aşamasında olduğu görülmektedir. Bu açıdan kapsamlı kuramsal ve amprik çalışmaların yapılmasına ihtiyaç duyulduğu ve özellikle kuramsal anlamda yapılan çalışmaların eksikliği dikkat çekmektedir. Son çalışmalar Neff'in öne sürdüğü kuramsal altyapının sınırlı kaldığını, alt boyutların öz şefkat doğasını yansıtmadı̆̆ını ifade ederek, Neff ölçeğinin uygun bir değerlendirme aracı olmadığını belirtmişlerdir (Khoury 2019; Muris ve Otgaar, 2020; Strauss ve diğerleri, 2016). Bu bağlamda gelecekte yapılacak araştırmalar ile Strauss ve diğerleri (2016) tarafından ortaya atılan beş boyutlu yapı ve geliştirilen ölçek değerlendirilmelidir. Öne sürülen yeni modelin sahip olduğu boyutlar arasındaki ilişkiler ortaya konularak ölçeğin geçerliliğinin test edilmesi elzemdir. Aynı zamanda başkalarına yönelik şefkat ile öz şefkat arasındaki ilişkiye dair daha fazla çalışma yapılması mevcut literatürü geliştirecektir.

Çalışma kapsamında ikinci olarak öz şefkatin örgüte olan etkileri yapılan araştırmalar ışı̆̆ında değerlendirilmiştir. Psikoloji literatüründe önemli bireysel 
güçlerden biri olarak görülen ve pek çok olumlu değişken ile birlikte değerlendirilen kavramın örgüte katkılarının yeterince keşfedilmediği görülmektedir. Yapılan çalışmalar değerlendirildiğinde ise öz şefkat düzeyi yüksek olan çalışanların örgütlerine bağlılık (Yalap ve Baygın, 2020) geliştirip daha prosoyal davranışlar sergilediği ve stres, tükenmişlik gibi olumsuzlukları kolay bertaraf edebildikleri (Dev ve diğerleri, 2018) gözlemlenmiştir. Aynı zamanda öz şefkatin yaratıcılık (Zabelina ve Robinson, 2010) ve duygusal zekâ (Fabio ve Saklofske, 2020) ile ilişkili olduğu ve performans üzerinde artırıcı etkisinden (Neff ve Knox, 2017) bahsedilmektedir. Genel bir çıkarım yapabilmek adına yapılan bu araştırmaların farklı örneklemler üzerinde tekrarlanması gerekmektedir. Dolayısıyla araştırmacıların yönünü organizasyonlara çevirip hem çalışanlar hem de yöneticiler açısından farklı sektörler içerisinde kavramın incelenmesi elzemdir. Ayrıca gelecekte yapılacak araştırmalarda örgütsel yabancılaşma, örgütsel yalnızlık, örgütsel özdeşleşme ve benzeri değişkenler ile öz şefkat arasındaki ilişkisinin ortaya konulması önerilmektedir. Aynı zamanda kişilik ve kuşaklar bazında yapılacak olan çalışmaların öz şefkat düzeyindeki bireysel farklılıkların anlaşılması hususunda katkı sağlayacağı düşünülmektedir.

Uygulayıcılar açısından değerlendirildiğinde ise öz şefkat örgütsel alanda istenilen davranışlar oluşturmada önemli bir kaynak olarak öngörülebilir. Öz şefkat düzeyi yüksek olan çalışanların örgüte katkısının da yüksek düzeyde olması muhtemeldir. Daha da önemlisi çalışanların olumsuz duygu ve durumlar ile baş etmesinde içsel bir güç olarak öz şefkatin katkı sağlayacağ1 düşünülmektedir. Bu açıdan uygulayıcılara çalışanların öz şefkat düzeylerini geliştirebilmelerine imkan tanıyan eğitimleri örgüt programlarına dahil etmeleri ve bu gelişime katkı sağlayacak güncel araştırmaları takip etmeleri önerilmektedir.

Sonuç olarak, yapılan çalışmalar öz şefkatin önemli bireysel güçlerden biri olduğunu ve kavram literatürünün günden güne geliştiğinin göstermektedir. Bu açıdan bu çalışmanın güncel araştırmalar ışı̆̆ında yararlı bir derleme olduğu düşünülmektedir. Aynı zamanda öz şefkatin örgüt perspektifinden ele alındığ1 herhangi bir çalışmaya alanyazınında rastlanmaması bu çalışmayı özgün kılmaktadır. $\mathrm{Bu}$ bağlamda çalışmanın araştırmacılara yön verme hususunda katkı sağlayacağı umulmaktadir. 


\section{KAYNAKÇA}

Abac1, R. ve Arda, D. (2013). Relationship between self-compassion and job satisfaction in white collar workers. Procedia - Social and Behavioral Sciences, 106, 2241-2247. doi: 10.1016/j.sbspro.2013.12.255

Aboul-Ela, G. M. (2017). Reflections on workplace compassion and job performance. Journal of Human Values, 23(3), 234-243. doi:10.1177/0971685817713285

Akın, A. (2008). Self-compassion and achievement goals: As tructural equation modeling approach. Eurasian Journal of Educational Research, 31, 1-15. https://www.semanticscholar.org/paper/Selfcompassion-and-Achievement Goals\%3A-A-StructuralAkin/8351d161b85792c753fe612ed4e4acf6c3db228d

Akın, Ü., Akın, A. ve Abacı, R. (2007). Öz-duyarlık ölçeği: geçerlik ve güvenirlik çalışması, Hacettepe Üniversitesi Eğitim Fakültesi Dergisi, $\quad$ 1-10. https://dergipark.org.tr/tr/pub/hunefd/issue/7805/102335

Aktaran, A. K. ve Üstündağ Budak, A. M. (2019). Attachment theory self-compassion and body image. The International Journal of Human and Behavioral Science, 5(2), 1-17. doi:10.19148/ijhbs.651271

Alibekiroğlu, P., Akbaş, T., Bulut Ateş, F. ve Kırkdök, O. (2018). Üniversite öğrencilerinde yaşam doyumu ile psikolojik sağlamlık arasındaki ilişkide öz anlayışın aracı etkisi. Çukurova Üniversitesi Sosyal Bilimler Enstitüsü Dergisi, 27 (2), 1-17. https:/ / dergipark.org.tr/tr/pub/cusosbil/issue/39773/471215

Alkema, K. Linton J. M. ve Davies R. (2008). A study of the relationship between self-care, compassion satisfaction, compassion fatigue, and burnout among hospice professionals. J. Soc. Work End Life Palliat. Care, 4, 101-119, doi: 10.1080/15524250802353934.

Allen, M., Roberts, C., J. Zimmer-Gembeck, M. ve J. Farrell L. (2020). Exploring the relationship between self-compassion and body dysmorphic symptoms in adolescents. Journal of Obsessive-Compulsive and Related Disorders, 25, 100535. doi: 10.1016/j.jocrd.2020.100535

Altıparmak D. (2019). Öğretmenlerin yaşam amacı ve anlamı düzeyleri ve iyi oluşları arasındaki ilişkide öz duyarlık değişkeninin aracı rolü. (Yayınlanmamış yüksek lisans tezi). İstanbul Sabahattin Zaim Üniversitesi, İstanbul.

Baer, R. A. (2003). Mindfulness training as a clinical intervention: a conceptual and empirical review. Clinical Psychology: Science and Practice, 10, 125-143. doi:10.1093/clipsy/bpg015

Barnard, L. K. ve Curry, J. F. (2011). Self-compassion: conceptualizations, correlates, \& interventions. Review of General Psychology, 15(4), 289-303. doi: 10.1037/a0025754

Bishop, S. R., Lau, M., Shapiro, S., Carlson, L., Anderson, N. D., Carmody, J., Segal Z., Abbey, S., Speca, M., Velting, D. ve Devins, G., (2004). Mindfulness: A proposed operational definition. Clinical Psychology Science and Practice, 11, 191-206. doi:10.1093/clipsy/bph077 
Breinesa, J., Toole, A. ve Chen, S. (2014). Self-compassion, body image, and self-reported disordered eating. Self and Identity, 13, 432-448. doi: 10.1080/15298868.2013.838992

Brown, B. (1999). Soul without shame: A guide to liberating yourself from the judge within. Boston: Shambala.

Deniz, M. E., Kesici Ş. S. ve Sümer A. S. (2008). The validity and reliability study of the Turkish version of self-compassion scale. An International Journal of Social Behavior and Personality, 36 (9), 1151-1160. doi: 10.2224/sbp.2008.36.9.1151

Dev, F., Fernando III A. T., Lim A. C. ve Consedine N. S. (2018). Does self-compassion mitigate the relationship between burnout and barriers to compassion? A cross-sectional quantitative study of 799 nurses. International Journal of Nursing Studies, 81, 81-88. doi: 10.1016/j.ijnurstu.2018.02.003

Dilmaç, B. ve Baş, A. (2019). Ergenlerin sahip oldukları değerler, öznel iyi oluşları ve sosyal kaygıları arasındaki yordayıcı ilişki. Manas Sosyal Araştırmalar Dergisi, 8 (4), 3685-3697. doi:10.33206/mjss.546820 Diedrich A., Hofmann S. G., Cuijpers P. ve Berking M. (2016). Self-compassion enhances the efficacy of explicit cognitive reappraisal as an emotion regulation strategy in individuals with major depressive disorder. Behav Res Ther. 82:1-10. doi:10.1016/j.brat.2016.04.003

Dutton, J. E., Frost, P., Worline, M. C, Lilius, J. M. ve Kanov, J. M. (2002). Leading in times of trauma. Harvard Business Review, 80(1): 54-61. https://hbr.org/2002/01/leading-in-times-of-trauma

Ekşi, H., İkiz, K. ve Başman, M. (2020). Üniversite öğrencilerinin mutluluk korkusu ve duygularını ifade etme becerileri arasındaki ilişkide öz duyarlılığın aracı rolü. Kastamonu Eğitim Dergisi, 28 (2), 820-829. doi: 10.24106/kefdergi.702904

Fabioa, A. D. ve Saklofske, D. H. (2020). The relationship of compassion and self-compassion with personality and emotional intelligence, Personality and Individual Differences, doi: 10.1016/j.paid.2020.110109

Falconer C. J., King J. A. ve Brewin C. R. (2015). Demonstrating mood repair with a situation-based measure of self-compassion and self-criticism. Psychol Psychother, 88: 351-6 doi: 10.1111/papt.12056

Finlay-Jones, A., Kane, R. ve Rees, C. (2017). Self-compassion online: A pilot study of an internet-based psychology Trainees. Journal of Clinical Psychology, 73(7):797-816. doi: 10.1002/jclp.22375

Frost, P. J., Dutton, J. E., Worline, M. C. ve Wilson, A. (2000). Narratives of compassion in organizations. In S. Fineman (Yay. haz.). Emotion in organizations içinde (s.25-45) . Thousand Oaks, CA: Sage.

Frost, P., Dutton, J.E., Maitlis, S., Lilius, J., Kanov, J. ve Worline, M. (2006). Seeing organizations differently: Three lenses on compassion. In C. Hardy, S. Clegg, T. Lawrence ve W. Nord (Yay. haz.). Handbook of organizational studies içinde (s. 843-866). London: Sage

Germer, C. K. ve Neff, K. D. (2013). Self-compassion in clinical practice. Journal of Clinical Psychology, 69(8), 856-867. doi: 10.1002/jclp.22021 
Gilbert, P. (2005). Compassion and cruelty: A biopsychosocial approach. P. Gilbert (Yay. haz.). Compassion: Conceptualisations, research and use in psychotherapy içinde(s. 9-74). Routledge.

Gilbert, P. ve Procter, S. (2006). Compassionate mind training for people with high shame and selfcriticism: Overview and pilot study of a group therapy approach. Clinical Psychology \& Psychotherapy, 13 (6), 353-379. doi: 10.1002/cpp.507

Gilbert, P. (2009). Introducing compassion-focused therapy. Advances in Psychiatric Treatment, 15(3), 199208. doi:10.1192/apt.bp.107.005264

Grant, A. M., Dutton, J. E., ve Rosso, B. D. (2008). Giving commitment: employee support programs and the prosocial sensemaking process. Academy of Management Journal, 51(5), 898-918. doi: 10.5465/AMJ.2008.34789652

Gilbert, P., McEwan, K., Matos, M. ve Rivis, A. (2011). Fears of compassion: Development of three selfreport measures. Psychology and Psychotherapy, 84, 239-255 doi: :10.1348/147608310X526511

Gu, J., Baer, R., Cavanagh, K., Kuyken, W. ve Strauss, C. (2020). Development and psychometric properties of the Sussex-Oxford Compassion Scales (SOCS). Assessment, 27,3 doi: $10.1177 / 1073191119860911$

Heffernan M., Quinn Griffin M. T., McNulty S. R. ve Fitzpatrick J. J. (2010). Self-compassion and emotional intelligence in nurses. International Journal of Nursing Practice, 16, 366-373. doi:10.1111/j.1440172X.2010.01853.x

Hollis-Walker, L. ve Colosimo, K. (2011). Mindfulness, self-compassion, and happiness in nonmeditators: A theoretical and empirical examination. Personality and Individual Differences, 50(2), 222227. doi:10.1016/j.paid.2010.09.033

Işık, E. (2018). Yetişkin kadınlarda öz-duyarlık ile beden algısı ve yeme tutumu arasındaki ilişkinin incelenmesi. (Yayınlanmamış yüksek lisans tezi). Maltepe Üniversitesi, İstanbul.

Jacobson, E. H. K., Wilson, K. G., Solomon Kurz, A. ve Kellum, K. K. (2018). Examining self-compassion in romantic relationships. Journal of Contextual Behavioral Science, 8, 69-73. doi: 10.1016/j.jcbs.2018.04.003

Kanov, J. M., Maitlis, S., Worline, M. C., Dutton, J. E., Frost, P. J. ve Lilius, J. M. (2004). Compassion in organizational life. American Behavioral Scientist, 47(6), 808-827. doi: 10.1177/0002764203260211

Kemper, K. J., McClafferty, H., Wilson, P. M., Serwint, J. R., Batra, M., Mahan, J. D., Schubert, C. J., Staples, B. B. ve Schwartz, A. (2019). Do mindfulness and self-compassion predict burnout in pediatric residents? Academic Medicine, 94(6), 876-884. doi: 10.1097/ ACM.0000000000002546.

Kim, C. ve Ko, H. (2018). The impact of self-compassion on mental health, sleep, quality of life and life satisfaction among older adults. Geriatr Nurs. 39(6), 623-628. doi:10.1016/j.gerinurse.2018.06.005 
Kirkpatrick, K. L. (2005). Enhancing self-compassion using a gestalt two-chair intervention, University of Texas at Austin, Unpublished doctoral dissertation.

Khoury, B. (2019). Compassion: embodied and embedded. Mindfulness, 10, 2363-2374. doi: $10.1007 / \mathrm{s} 12671-017-0858-\mathrm{z}$

Kousar, S., Perveen, M. K., Afzal, M. M., Waqasr, M. A. ve Gilani, S. A. (2017). The impact of selfcompassion and emotional intelligence among registered nurses. Saudi Journal of Medical and Pharmaceutical Sciences, 3(6A), 493-499. doi: 10.21276/sjmps

Korkmaz, B. (2018). Öz Duyarlık: Psikolojik belirtiler ile ilişkisi ve psikoterapide kullanımı. Psikiyatride Güncel Yaklaşımlar-Current Approaches in Psychiatry, 10 (1), 40-58. doi:10.18863/pgy.336489

Leary, M. R., Tate, E. B., Adams, C. E., Allen, A. B. ve Hancock, J. (2007). Self-compassion and reactions to unpleasant self-relevant events: the implications of treating oneself kindly. Journal of Personality and Social Psychology, 92,887-904. doi: 10.1037/0022-3514.92.5.887

Lilius, J. M., Worline, M. C., Dutton, J. E., Kanov, J. M., Frost, P. J. ve Maitlis, S. (2003). What good is compassion at work? Unpublished manuscript, University of Michigan.

Lilius J.M., Worline M.C., Maitlis S., Kanov, J. M., Dutton, J. E. ve Frost, P. (2008). The contours and consequences of compassion at work. Journal of Organizational Behavior 29(2): 193-218. doi:10.1002/job.508

Lindsay, E. K. ve Creswell, J. D. (2014). Mindfulness, acceptance, and emotion regulation: perspectives from monitor and acceptance theory (mat). Current Opinion in Psychology, 28, 120-125. doi:10.3389/fpsyg.2014.00421

Longe, O., Maratos, F. A., Gilbert, P., Evans, G., Volker, F., Rockliff, H. ve Rippon, G. (2010). Having a word with yourself: neural correlates of self-criticism and self-reassurance. Neuroimage, 49, 1849-1856. doi: 10.1016/j.neuroimage.2009.09.019

Luo Y., Meng R., Li J., Liu B., Cao X. ve Ge W. (2019). Self-compassion may reduce anxiety and depression in nursing students: a pathway through perceived stress. Public Health. 174:1-10. doi: 10.1016/j.puhe.2019.05.015

MacBeth, A. ve Gumley, A. (2012). Exploring compassion: A meta-analysis of the association between self-compassion and psychopathology. Clinical Psychology Review, 32, 545- 552. doi: 10.1016/j.cpr.2012.06.003

Mete, M., Vakkas, A. ve Aksoy, C. (2016). Çalışma hayatında duygusal düzenleme. TURAN-SAM Uluslararası Bilimsel Hakemli Dergisi, 8(29), 15-23. https://www.turansam.org/TURAN-SAM_29.pdf

Moon, T. W., Hur, W. M., Ko, S. H., Kim, J. W. ve Yoon, D. K. (2016). Positive work-related identity as a mediator of the relationship between compassion at work and employee outcomes. Human Factors and Ergonomics in Manufacturing E Service Industries, 26(1), 84-94. doi: 10.1002/hfm.20615 
Muris, P. ve Otgaar, H. (2020). The process of science: A critical evaluation of more than 15 years of research on self-compassion with the Self-Compassion Scale. Mindfulness, 11(6), 1469-1482. https://doi.org/10.1007/s12671-020-01363-0.

Nas E. ve Sak R. (2020). Merhamet ve merhamet odaklı terapi, Celal Bayar Üniversitesi Sosyal Bilimler Dergisi, 18 (1); 64-84. doi: 10.18026/cbayarsos.525744

Neely, M. E., Schallert, D. L., Mohammed, S. S., Roberts, R. M. ve Chen, Y. (2009). Self-kindness when facing stress: the role of self-compassion, goal regulation, and support in college students well-being. Motivation and Emotion, 33, 88-97. doi: 10.1007/s11031-008-9119-8

Neff, K. D. (2003a). The development and validation of a scale to measure self compassion. Self and Identity, 2(3), 223-250. doi: 10.1080/15298860309027

Neff, K. D. (2003b). Self compassion: an alternative conceptualization of a healthy attitude toward oneself. Self and Identity, 2, 85-102. doi:10.1080/15298860309032

Neff, K. D. (2004). Self-compassion and psychological well-being. Constructivism in the Human Sciences, 9, 27-37. https://sites.google.com/site/constructingworlds/vol.9(2004)

Neff, K. D., Hsieh, Y. P. ve Dejitterat, K. (2005). Self-compassion, achievement goals, and coping with academic failure. Self and Identity, 4(3), 263-287. doi: 10.1080/13576500444000317

Neff, K. D. (2008). Self-compassion: moving beyond the pitfalls of a separate self-concept. In J. Bauer ve H. A. Wayment (Yay. haz.). Transcending Self-Interest: Psychological Explorations of the Quiet Ego içinde (s. 95-105). APA Books, Washington DC.

Neff, K. D. ve McGehee, P. (2010). Self-compassion and psychological resilience among adolescents and young adults. Self and Identity, 9(3), 225-240. doi: 10.1080/15298860902979307

Neff, K. D. (2011). Self Compassion, self esteem and well-being. Social and Personality Psychology Compass, 5(1) 1-12. doi: 10.1111/j.1751-9004.2010.00330.x

Neff, K. D. ve Beretvas S. N. (2012). The role of self-compassion in romantic relationships. Self and Identity, 12 (1), 78-98. doi. 10.1080/15298868.2011.639548

Neff K. D. ve Tirch D. (2013). Self-compassion and act. Kashdan T.B. ve Ciarrochi J. (Yay. haz.). Mindfulness, acceptance, and positive psychology: the seven foundations of well-being içinde (s. 78-106). Oakland, CA: Context Press/New Harbinger Publications.

Neff, K. D. (2016). The Self-compassion scale is valid and theoretically coherent measure of self compassion. Mindfulness, 7(1), 264-274. doi: 10.1007/s12671-015-0479-3

Neff, K. D. ve Knox, M. C. (2017). Self-compassion. V. Zeigler-Hill, TK Shackelford (eds.), Encyclopedia of Personality and Individual Differences, 1-8. doi: 10.1007/978-3-319-28099-8_1159-1 
Neff, K. D. ve Germer, C. (2017). Self-compassion and psychological well-being. J. Doty (Yay. haz.). Oxford Handbook of Compassion Science içinde (s. 27). Oxford University Press.

Omay, Z. M. (2019). Üniversite öğrencilerinin öz anlayış düzeylerinin hayat memnuniyeti ve dindarlık yönelimleri açısından incelenmesi (M. Ü. İlahiyat Fakültesi öğrencileri örneği). (Yayınlanmamış yüksek lisans tezi). Marmara Üniversitesi, İstanbul.

Öveç, Ü. (2007). Öz-duyarlı ile öz- bilinç, depresyon, anksiyete ve stres arasındaki ilişkilerin yapısal eşitlik modeliyle incelenmesi. (Yayınlanmamış yüksek lisans tezi). Sakarya Üniversitesi, Sakarya.

Raab, K. (2014). Mindfulness, self-compassion, and empathy among health care professionals: a review of the literature. Journal of Health Care Chaplaincy, 20(3), 95- 108. doi:10.1080/08854726.2014.913876

Raes, F., Pommier, E., Neff, K. D. ve Van Gucht, D. (2011). Construction and factorial validation of a short form of the self-compassion scale. Clinical Psychology and Psychotherapy, 18(3), 250-255. doi: $10.1002 /$ cpp.702.

Rogers, C. R. (1961). On becoming a person: A therapist's view of psychotherapy. Houghton Mifflin, Boston. Simões, D., Simões, S., Espírito-Santo, H., Simões, D., Marques, M. ve Lemos, L. (2016). Mental health, self-compassion, organizational virtuosity and commitment in workers from local administration. European Psychiatry, 33(S1), S519-S520. doi: 10.1016/j.eurpsy.2016.01.192

Simpson, A. W. (2012). Organizational compassion as a complex social relational process. Doktora Tezi. Sydney University of Technology, Sydney.

Strauss, C., Taylor, B. L., Gu, J., Kuyken, W., Baer, R., Jones, F. ve Cavanagh, K. (2016). What is compassion and how can we measure it? A review of definitions and measures. Clinical Psychology Review, 47, 15 doi: 10.1016/j.cpr.2016.05.004

Stoeber, J., Lalova, A. V. ve Lumley, E. J. (2020). Perfectionism, (self-) compassion, and subjective wellbeing: a mediation model. Personality and Individual Differences, 154. doi: 10.1016/j.paid.2019.109708.

Şenyuva E., Kaya H., Işık B. ve Bodur G. (2013). Relationship between self-compassion and emotional intelligence in nursing students. International Journal of Nursing Practice, 20,1-9. doi:10.1111/ijn.12204

Tatlılığlu, K. (2010). Farklı öz-anlayış düzeylerine sahip üniversite öğrencilerinin karar vermede özsaygı, karar verme stilleri ve kişilik özelliklerinin değerlendirilmesi. (Yayınlanmamış yüksek lisans tezi). Selçuk Üniversitesi, Konya.

The Oxford dictionary (3rd ed.). (2000). Oxford University Press.

Wilson, J. M., Weiss, A. ve Shook, N.J. (2020). Mindfulness, self-compassion, and savoring: factors that explain the relation between perceived social support and well-being. Personal Individual Differences, 152: 1-9. doi: 10.1016/j.paid.2019.109568 
Yalap, O. ve Baygın, E. (2020). Psikolojik sermaye ve örgütsel bağlılık etkileşimi: öz-şefkatin aracı rolü. Journal of Organizational Behavior Review, 2 (1), https://dergipark.org.tr/tr/pub/jobreview/issue/51579/655400

Yang, Y., Zhang, M. ve Kou, Y. (2016). Self-compassion and life satisfaction: the mediating role of hope. Personality and Individual Differences, 98, 91-95. doi: 10.1016/j.paid.2016.03.086

Yaşa E. N. (2019). Sağhık çalışanlarının, bilişsel duygu düzenleme stratejilerinin ve öz anlayış düzeylerinin anksiyete düzeyleri ile ilişkisinin incelenmesi. (Yayınlanmamış yüksek lisans tezi). İstanbul Gelişim Üniversitesi, İstanbul.

Zabelina, D. L. ve Robinson, M. D. (2010). Don't be so hard on yourself: Self-compassion facilitates creative originality among self-judgmental individuals, Creativity Research Journal, 22: 3, 288-293. doi: $10.1080 / 10400419.2010 .503538$

Zessin, U. Dickhauser, O. ve Garbade, S. (2015). The relationship between self-compassion and wellbeing: a meta-analysis. Applied Psychology: Health and Well-Being, 340-364. doi:10.1111/aphw.12051 